\title{
Epistemic Fallacy Menurut Roy Bhaskar
}

\author{
Imam Wahyudi ${ }^{1}$, Rangga Kala Mahaswa ${ }^{1,2}$ \\ ${ }^{1}$ Fakultas Filsafat, Universitas Gadjah Mada, Yogyakarta, Indonesia \\ 2 Ze-No, Centre for Logic and Metaphysics, Yogyakarta, Indonesia \\ E-mail: imamfil@ugm.ac.id1', rangga.mahaswa@gmail.com²
}

\begin{abstract}
Abstrak
Artikel ini bertujuan untuk memberikan deskripsi analisis terkait pandangan epistemic fallacy Roy Bhaskar dan kritiknya terhadap perkembangan epistemologi positivisme dan posmodernisme. Metode penelitian ini menggunakan studi kepustakaan dengan merujuk pada diskursus epistemologi, perkembangan realisme kritis Roy Bhaskar, dan rumusan epistemic fallacy atau kekeliruan epistemik. Kekeliruan epistemik merupakan kritik Roy Bhaskar yang berdasarkan kerangka realisme kritis. Realisme kritis sebagai sebuah pendekatan menemukan bahwa adanya kecenderungan reduksionisme dan tumpang-tindih perihal pemahaman yang-ada dan yangdiketahui. Oleh karena itu, kesalahan epistemik dapat diatasi dengan membangun pemahaman epistemologi relativistik agar tidak terjebak antara solipsisme posmodernisme (subjektivisme naif) atau universalitas nilai model positivisme logis (objektivisme naif).
\end{abstract}

Kata Kunci: epistemic fallacy; posmodernisme; positivisme; realisme kritis.

\begin{abstract}
This article aims to provide an analytical description of Roy Bhaskar's epistemic fallacy and his critique of positivism and postmodernism. The research method uses literature study by referring to epistemology discourse, critical realism view, and the nature of epistemic fallacy. Epistemic fallacy accordingly is the anthropic fallacy because it contains inconsistency in the idea that the argument about being is to be investigated in terms of our knowledge of being. Critical realism finds reductionist and overlapping about what is and what is to be. The epistemic fallacy has also issued several misconceptions, such as uniformitarianism, declining open system, and flat ontology. Therefore, since ontology cannot be reduced into epistemology, relativistic epistemology is part of the Critical Realism notion to overcome solipsism and naïve universalism.
\end{abstract}

Keywords: epistemic fallacy; postmodernism; positivism; critical realism.

\section{Pendahuluan}

Roy Bhaskar (1944-2014) merupakan salah satu filsuf ilmu yang mengembangkan pandangan realisme kritis untuk menyelesaikan persoalan perkembangan filsafat ilmu, terutama kritiknya terhadap metodologi positivisme logis dan posmodernisme. Bhaskar juga berbicara mengenai persoalan naturalisme antara ilmu alam dan ilmu sosial. Realisme Kritis merupakan salah satu strategi Bhaskar untuk mengatasi distingsi antara subjek dan objek, individu dan masyarakat, nilai dan fakta, serta bagaimana teori dan praksis bekerja pada bidang ilmu.

Selain itu, sebagaimana pandangan realisme yang bergerak di ranah metafisika, Bhaskar berusaha membaca proses transformasi sosial dan daya emansipatoris kritis bekerja. Pada tahapan lebih lanjut, filsafat Bhaskar mengarah pada filsafat meta-realitas. Selain itu, Bhaskar juga memiliki pandangan yang khas terhadap dimensi epistemologi dan dimensi aksiologis terkait ilmu. Meskipun seorang realis, pandangan Bhaskar tentang epistemologi tidak dapat diabaikan begitu saja. Bhaskar sangat menaruh perhatian terhadap bagaimana tren pandangan filsafat ilmu membawa pengaruh yang cukup signifikan terhadap keputusan epistemik yang diambil oleh ilmuwan (Fleetwood, 2014).

Pembahasan penting Bhaskar dimulai ketika menyadari bahwa posmodernisme dan positivisme logis terjebak pada cara pandang yang cukup naif. Posmodernisme memandang ciri khas pengetahuan hanya berlatar pada dekonstruksi daripada rekonstruksi makna. Ilmu hanya dianggap sebagai sesuai yang tunggal-absolut menjadi ragam-relatif. Oleh karena itu, tidak heran apabila posmodernisme lebih memercayai bahwa ilmu selalu berkorelasi dengan subjek dan menolak nilai yang objektif. Sedangkan di satu sisi, positivisme justru mengabaikan peran subjek 
dalam mempertimbangkan suatu makna atau nilai terhadap objek. Menurut Bhaskar, kedua kecenderungan ini masih terlalu naif untuk dapat membedakan antara ranah ontologis dengan epistemologis dari suatu objek ilmu.

Berpijak dari persoalan di atas, Bhaskar lalu berusaha untuk menjelaskan bahwa realisme kritis dapat menjadi jalan tengah untuk menyelesaikan persoalan antara positivisme logis dan posmodernisme. Bhaskar percaya bahwa dunia filsafat ilmu sampai hari ini masih diselimuti bayang-bayang absurd terkait kesalahan atau kekeliruan epistemik (epistemic fallacy). Kesalahan epistemik ini telah membawa konsekuensi logis penyebab terjadinya perdebatan antara positivisme logis dengan posmodernisme yang hanya mengklaim salah satu kutub saja, di antara posmodern yang menganut solipsisme ekstrem (subjektivisme naif) dengan positivisme logis yang menganut universalitas nilai (objektivisme naif). Artinya, kesalahan epistemik yang dibawa oleh kedua aliran ini telah memberikan reduksi dari sesuatu yang menjadi fokus pertanyaan ontologis justru disederhanakan dan diselesaikan pada jawaban epistemologis yang definitif (Hartwig, 2015).

Bhaskar merasa bahwa apa yang menjadi being kurang tepat jika didiskusi dalam ruang epistemic. Selain itu, Bhaskar dengan tegas mengkritik kesalahan positivisme logis dan posmodernisme dalam memahami yang-riil secara reduksionis. Pada posisi ini, penelitian ini kemudian akan menelusuri secara lebih mendalam terkait pandangan epistemologi Realisme Kritis Roy Bhaskar untuk menunjukkan penyelesaian dari persoalan kesalahan epistemik yang selama ini dipahami oleh para pemikir positivisme maupun posmodernisme. Oleh karena itu, penelitian ini akan menjadi penelitian yang eksploratif terkait konsep epistemologi Roy Bhaskar terutama tentang kesalahan epistemik serta posisinya terhadap konstruksi pengetahuan yang terbangun secara realis tanpa harus terjebak sebagaimana positivisme logis maupun posmodernisme.

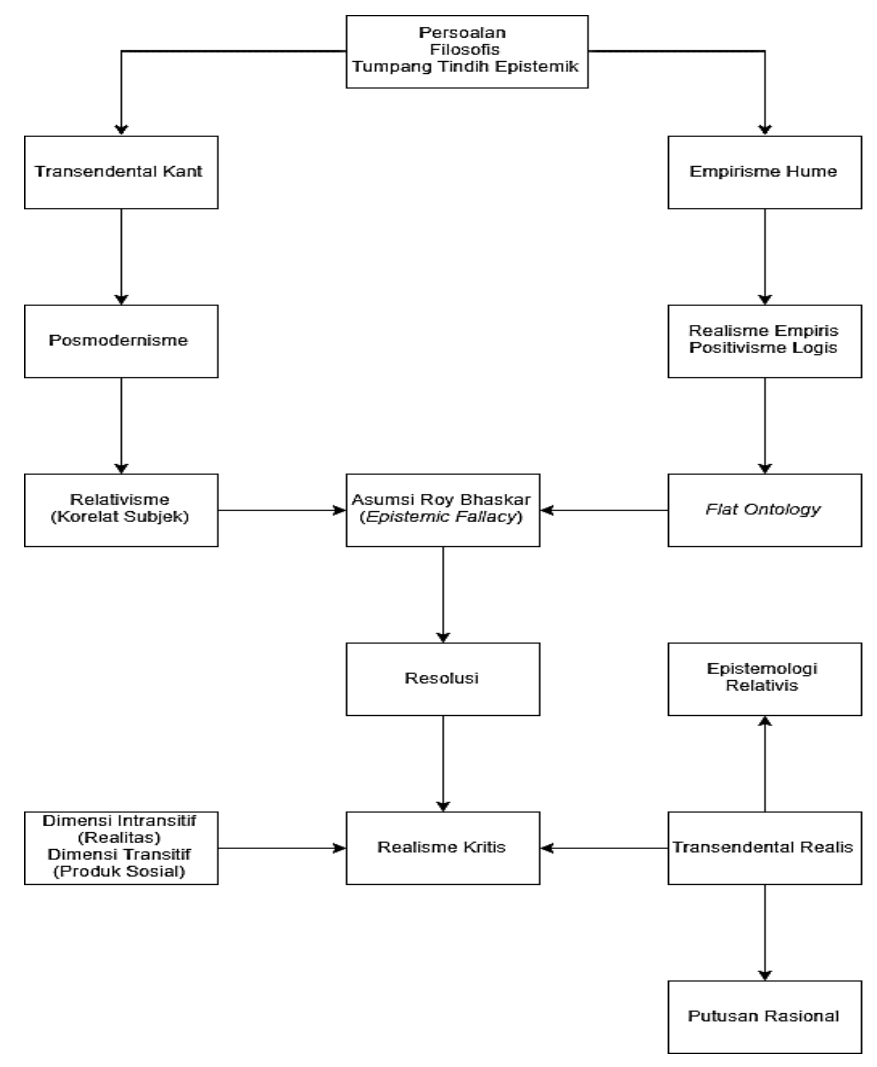

Gambar 1. Kerangka Berpikir Penelitian

Adapun batasan-batasan terhadap pembahasan epistemologi realisme kritis mengarah pada pembahasan awal terkait epistemic fallacy sekaligus tidak menjebak diri pada polemik antara positivisme dengan posmodernisme. Asumsi inilah yang harus diselesaikan oleh peneliti terkait cara landasan metodologi keilmuan bekerja. Pertama, terlebih dahulu harus dipisahkan pandangan keduanya secara ontologi, epistemologi, dan aksiologi. Kedua, mengemukakan cara 
kesalahan epistemik bekerja untuk menarik pada simpulan pentingnya relativitas epistemologi. Ketiga, memahami perbedaan untuk menarik satu simpulan bahwa realisme kritis dapat mengkritik empirisme naif dan solipsisme sekaligus.

Setelah menyelesaikan persoalan demarkasi ontologi dan epistemologi, Bhaskar lalu mengkritik ketidakselarasan antara penerapan pada realisme empirisme ala Humean maupun reduksi seluruh realitas atas dasar kesadaran subjek (posmodernisme). Oleh karena itu, menurut Bhaskar, realisme, terutama realisme kritis, mesti menerima pandangan relativitas epistemologis. Hal ini dikarenakan semua kepercayaan dan pengetahuan merupakan bagian dari produk sosiohistoris yang termasuk dimensi transitif sains sehingga dapat keliru.

Pernyataan ini berbeda dengan jenis relativisme (judgemental relativism) yang menyatakan bahwa semua kepercayaan/pengetahuan sama benarnya sebab tak ada kriteria dasar universal yang dapat memilah pengetahuan yang benar dari yang keliru (Bhaskar, 2014). Relativisme epistemologis dapat menjaga realisme dari bahaya jatuhnya sikap ideologis yang niscaya terkait paradigma teoritis yang sedang digunakan. Dalam arti itu, Bhaskar menyebut relativitas epistemologis sebagai 'tangan kanan' realisme (Suryajaya, 2014).

Berdasarkan pendahuluan ini, artikel ini bertujuan untuk memberikan deskripsi analisis terkait kritik kekeliruan epistemik yang berkembang di antara dua epistemologi positivisme dan posmodernisme dengan menggunakan kerangka realisme kritis. Hasil pembahasan artikel kemudian dapat dijadikan pertimbangan alternatif dalam memahami ilmu secara realisme kritis dan menghindari pandangan yang keliru secara epistemik terhadap status ontologis ilmu.

\section{Metode}

Metode penelitian yang digunakan merupakan studi kepustakaan yang didukung dengan sumber primer dan sekunder yang relevan. Penelitian berfokus pada studi pandangan epistemologi Roy Bhaskar terutama pada gagasan epistemic fallacy atau kekeliruan epistemik. Prosedur penelitian ini dengan cara inventarisasi sumber, identifikasi data, dan analisis filosofis kritis sehingga menemukan pola, corak, dan konsep terkait epistemic fallacy menurut Roy Bhaskar.

\section{Hasil dan Pembahasan}

\section{a. Epistemologi dan Realisme IImiah}

Epistemologi secara etimologis merujuk kata episteme yang berarti pengetahuan, dan logos yang artinya ilmu. Dengan kata lain epistemologi merupakan suatu ilmu mengenai pengetahuan. Epistemologi sebagai cabang filsafat berfokus mengenai kajian atas diskursus pengetahuan, seperti i) apa yang dimaksud sebagai pengetahuan, ii) bagaimana pengetahuan itu didapat, iii) apakah kepercayaan yang dapat dijustifikasikan sebagai benar dapat dinyatakan sebagai pengetahuan, iv) bagaimana suatu kriteria kita dapat menyatakan suatu hal sebagai benar, dan lain sebagainya (Pritchard, 2018). Salah satu diskursus dan kajian dalam epistemologi adalah dengan menempatkan bagaimana suatu pengetahuan itu bersumber atau berasal, seperti suatu pengetahuan dapat bersifat a priori atau melampaui pengalaman dan bersifat a posteriori yang berarti suatu pengetahuan bersumber dari pengalaman (Kitcher, 1984).

Epistemologi ilmiah menurut Carl Wenning (2009) bahwa epistemologi dan ilmu selalu beririsan sebab mempertanyakan ulang jarak hubungan antara kepercayaan kita terhadap sesuatu dengan pengetahuan kita terhadap sesuatu. Hakikat pengetahuan secara klasik dijelaskan pada model epistemologi yang berbasis pada Justified True Belief atau JTB, yang mengandaikan $\mathrm{X}$ adalah benar, kita percaya $\mathrm{x}$, dan kita menjustifikasi adanya $\mathrm{x}$. Secara umum, cara kita mengetahui tentang dunia belum tentu hal yang ilmiah. Beberapa keilmiahan ditentukan oleh cara memperoleh pengetahuan ilmiah antara lain melalui pendekatan umum seperti rasionalisme, reliabilisme, koherentisme, empirisme, serta termasuk turunannya yang mengarah pada model penyimpulan tertentu (induksi, deduksi, dan abduksi) (Wenning, 2009). Meskipun demikian, pengetahuan ilmiah memiliki cakupan dan batasan terkait bagaimana suatu teori dapat dijelaskan dan dikonfirmasi lebih lanjut.

Pada satu sisi, epistemologi ilmu menjelaskan tentang tujuan ilmu, progres kerja ilmiah, hakikat bukti ilmiah, kritik metodologi ilmiah, dan bahkan problem antara dimensi justifikasi dengan dimensi temuan dalam ilmu (Bird, 2010). Epistemologi ilmu menekankan progres ilmiah sebagai bentuk akumulasi pengetahuan memiliki beberapa hubungan intrinsik terkait pembuktian suatu teori ilmiah dengan kenyataan atau objek dari ilmu tersebut. Terdapat semacam ruang abu- 
abu (grey area) di antara observasi dan justifikasi suatu ilmu itu sendiri. Hal tersebut yang menjadi salah satu topik perenial dalam epistemologi ilmu.

Niiniluoto dalam Critical Scientific Realism memformulasikan realisme sebagai suatu hal yang bermakna totalitas dari suatu objek yang riil. Realisme sebagai doktrin filosofis mengartikulasikan realitas dari suatu objek yang terbagi menjadi realisme ontologis (Apakah terdapat realitas yang mandiri dari dunia?); epistemologis (Apakah pengetahuan terhadap dunia yang mandiri dari pikiran dapat dimungkinkan?); aksiologis (Apakah kebenaran merupakan tujuan dari penyelidikan ilmiah?); etis (Apakah nilai moral suatu hal yang eksis di dunia?); dan semantik (Apakah kebenaran merupakan relasi yang objektif antara dunia dan bahasa?) (Niiniluoto, 1999). Bhaskar secara langsung menyatakan bahwa epistemologi yang dikerjakan oleh Bhaskar hanya memuat tingkat seorang ilmuwan memahami realitas sebagai entitas yang digunakan untuk dasar konstruksi ilmu. Suatu ilmu dapat dimungkinkan bila adanya komitmen secara ontologis bahwa realitas bersifat independen dan memiliki dimensi riil yang intrinsif. Adapun pertanyaan sentral yang diangkat oleh Bhaskar adalah, dunia semacam apa yang mampu memungkinkan adanya sains dan sains semacam apa yang memungkinkan adanya dunia? (Suryajaya, 2014).

Realisme ilmiah dibangun dalam suatu komitmen terhadap entitas yang di luar dari kesadaran manusia. Dalam suatu pandangan tertentu realisme ilmiah didefinisikan sebagai suatu posisi yang menekankan pada aspek pencapaian epistemik dari suatu teori ilmiah seperti aproksimasi kebenaran dari suatu teori ilmiah. Realisme ilmiah juga dapat didefinisikan sebagai hubungan korespondensi antara suatu term teoritis tertentu terhadap suatu rujukan di dunia (yang terobservasi maupun yang tidak terobservasi). Di antara semua definisi tersebut terdapat penekanan terhadap komitmen pada teori ilmiah terbaik yang memuat suatu status epistemik tertentu yang memungkinkan akses terhadap suatu hal di dunia termasuk entitas yang tidak terobservasi (Chakravartty, 2007, 2011).

Asumsi metafisis realisme ilmiah selalu berdasar pada argumen bahwa realitas bersifat independen dari pikiran manusia (Chakravartty, 2007). Bagi Bas van Fraasen (1980) dalam basis epistemologis realisme ilmiah bertujuan menghasilkan kebenaran ilmiah yang selalu berusaha menuju kebenaran ilmiah sejati terhadap realitas. Realisme ilmiah, mendasarkan pada sikap epistemik tertentu terhadap realitas yang termaktub dalam penyelidikan ilmiah, entah itu yang terobservasi maupun yang tidak terobservasi. Realitas yang tidak terobservasi, merujuk pada keadaan realitas yang tidak bisa secara langsung terobservasi, tetapi terakses berdasarkan pada pengondisian dan intervensi. Yang tidak terobservasi adalah instrumen, bukan terletak pada domain pemikiran namun di dalam domain riil (Hacking, 1984).

Dalam kerangka semantis, realisme ilmiah melihat suatu entitas teoritis tertentu dapat dinyatakan terobservasi atau tidak terobservasi ketika dapat dinyatakan memiliki nilai kebenaran yang dapat ditentukan sebagai benar atau salah. Berbeda dari itu instrumentalis yang mengklaim bahwa entitas tak terobservasi tidak memiliki makna yang definif sehingga tidak dapat dimaknai secara harfiah selain melalui entitas yang terobservasi (Chakravartty, 2011).

Teori ilmiah dapat dinyatakan benar ketika suatu teori tersebut mampu secara kuat memberikan aspek deskripsi terhadap realitas, tidak semata-mata ad hoc, bersifat prediktif, dan memberikan kebaruan (novelty). Terdapat dua kategori teori ilmiah, teori ilmiah dapat dinyatakan matang ketika merujuk pada suatu teori yang mampu bertahan dari kritik dan pembuktian. Teori ilmiah yang matang, dipercaya lebih kuat sebagai jalan untuk memahami realitas. Suatu teori selalu mungkin untuk salah. Teori ilmiah perlu dikualifikasikan dengan menentukan derajat keilmiahannya (Chakravartty, 2007).

\section{b. Realisme Kritis Roy Bhaskar}

Bhaskar berani mendobrak panorama filsafat kontemporer dengan memberikan kritik atas positivisme dan posmodernisme sebagai dasar pijakan metodologi ilmu pengetahuan. Positivisme terbukti mereduksi realitas objektif ke realitas yang teramati dan menganggapnya sebagai fakta empirik yang final. Sedangkan pascamodernisme mereduksi realitas objektif ke wilayah yang berkorelasi secara konstitutif dengan manusia, baik via kesadaran-ketidaksadaran, tubuh, bahasa, intensionalitas, dan pengalaman faktis-eksistensial.

Bhaskar mengklaim bahwa keduanya sama-sama melakukan reduksi atas realitas yang menempatkan manusia sebagai sentral, asumsinya, realitas tidak akan terpahami tanpa mengasumsikan adanya manusia. Bhaskar menyebut keduanya sebagai penganut anti-realisme yang memungkinkan akan terjatuh pada solipsisme. Secara metodologis, keputusan subjek atau institusi ilmiah yang mengarah pada kekeliruan epistemik menjadikan sains tidak dimungkinkan. 
Sains dalam strategi pertanyaan transendental Bhaskar ialah terkait "apa saja syarat yang memungkinkan bagi adanya sains?". Bhaskar menarik dua syarat utama sains dimungkinkan melalui dimensi transitif dan atau dimensi intransitif (Bhaskar, 2008).

Selain itu, Bhaskar dapat dikategorikan sebagai realisme entitas meskipun tidak secara eksplisit menunjukkan hal tersebut. Realisme entitas (entity realism) sendiri dapat dipahami sebagai suatu pandangan bahwa dalam kondisi tertentu seseorang dapat menunjukkan pengetahuan kausal yang mengesankan dari suatu entitas yang tidak dapat diobservasi, seperti pengetahuan yang memberikan akses bagi intervensi terhadap entitas tertentu dan penggunaannya melalui campur tangan dalam fenomena lain (Chakravartty, 2011).

Realitas yang terstruktur dan mekanistik bagi Bhaskar mandiri dari regularitas peristiwa yang dihasilkan, sama seperti peristiwa yang riil dan berbeda dari pengalaman yang membuat mereka tercerap. Dengan demikian, mekanisme, peristiwa, dan pengalaman merupakan tiga domain realitas yang saling tumpang tindih. Strategi yang dilakukan oleh Bhaskar untuk mengatasi persoalan di atas, yaitu dengan cara membuat strata pada realitas via realisme transendental. Realisme mengakui adanya sentralitas dimensi intransitif dari pengetahuan dan arti transendental berpijak pada pertanyaan mengenai syarat kemungkinan ontologis bagi adanya suatu pengetahuan (Suryajaya, 2014).

Bhaskar mengkritik empirisme dengan menyatakan bahwa objek pengetahuan tidak berhenti hanya pada benda-benda empirik semata sebagai atom dan peristiwa sebagai interaksi antar atom tersebut. Akan tetapi, mestinya juga mencapai penjelasan tentang struktur, tendensi atau mekanisme yang inheren dalam realitas kendati tak teramati secara empirik sama sekali. Dalam melawan idealisme, Bhaskar menyatakan bahwa ada dimensi intransitif yang konstitutif terhadap adanya pengetahuan. Meskipun pengetahuan dibentuk oleh pengalaman intersubjektif, tetapi objek pengetahuan itu bisa ada tanpa adanya subjektivitas dan intersubjektivitas (Suryajaya \& Apinino, 2016).

Dalam pandangan ini menekankan bahwa seluruh pengetahuan berpusat pada aspek perseptual manusia, posisi ini mengabaikan aspek struktur multidimensional dunia yang mandiri dari manusia. Posisi ini yang disebut sebagai flat ontology, dalam pandangan ini dunia dipipihkan ke dalam suatu bidang datar dan seluruh karakteristik dideterminasikan berdasarkan kebutuhan epistemik dari suatu pengetahuan tertentu (Archer et al. 2013).

Flat ontology dapat dinyatakan bahwa tugas metafisika hanya menempatkan status suatu entitas tertentu masuk ke dalam suatu kelas tertentu atau tidak (Schaffer, 2009). Misalnya dengan menyatakan bahwa elektron eksis maka dengan demikian elektron dinyatakan dapat dikategorikan dalam suatu klasifikasi entitas yang eksis. Posisi ini ditolak oleh Bhaskar dengan menawarkan realitas yang terstratifikasi dan struktur secara hierarkis yang mensyaratkan adanya tiga domain realitas \{riil (Dr), aktual (Da), dan empiris (De)\} (Bhaskar, 2008).

Domain riil merupakan struktur mekanisme yang imanen dalam realitas, sebagai objek sesungguhnya dari pengetahuan yang valid. Struktur ini tidak tampak secara langsung pada observasi empiris dan aktualitas peristiwa. Domain aktual bagian dari efek mekanisme-struktur riil yang inheren dalam peristiwa yang teramati. Subjek dapat mengamati domain ini pada sistem tertutup yang berbeda dengan domain empiris yang lebih terbuka. Hubungan ketiganya menjadi: $\mathrm{Dr} \geq \mathrm{Da} \geq \mathrm{De}$ (Bhaskar, 2008).

One aspect of this is the view, which I have characterized as the epistemic fallacy, that ontological questions can always be rephrased as epistemological ones. The anthropocentric and epistemic biases of classical philosophy led to the dissolution of the concept of the ontological realm, which we need to render intelligible the transitive process of science. In this way the world, which ought to be viewed as a multi-dimensional structure independent of man, came to be squashed into a flat surface whose characteristics, such as being constituted by atomistic facts, were determined by the needs of a particular concept of knowledge. This led to a barrage of problems and an impossible account of science. For from now on any structure, if it was allowed at all, had to be located in the human mind or the scientific community (Archer et al., 2013).

Positivisme logis maupun realisme empiris melakukan uji proses eksperimen mengandalkan prakondisi yang diduga memunculkan peristiwa tertentu yang terpilah-pilah via uji-coba. Regularitas empiris selalu muncul dalam eksperimen (sistem penutupan-closure) hasil dari fabrikasi ilmuwan, artinya konjungsi antar fenomena tidak terdapat melainkan yang ilmuwan 
ciptakan. Kondisi ini berarti mengisolasi prakondisi tertentu sehingga memunculkan peristiwa yang bertautan positif-kausal (Bhaskar, 2008). Dengan demikian, jawaban agar memungkinkan adanya sains maka harus mengafirmasi dunia yang terbuka, tidak sekedar isolasi-eksperimental untuk dapat menemukan struktur-mekanisme riil, atau hanya sekedar mencatat pola regularitas peristiwa. Kenyataannya, ilmuwan selalu berhadapan dengan sistem yang terbuka terhadap keberagaman mekanisme atau struktur yang non-empirik dan inheren dalam setiap benda serta peristiwa.

Menurut Bhaskar (2008) tugas ilmuwan yang realis ialah mencari dimensi intransitif fenomena kausal yang sering ditemukan dalam sistem tertutup itu, bukan sekadar memverifikasi regularitas empiris semata tetapi juga struktur implisit yang sudah ada tanpa adanya eksperimen dan pengamatan. Oleh karena itu, sains merupakan upaya sistematis yang ilmiah untuk mengekspresikan struktur dan modus tindakan benda-benda yang ada secara independen terhadap pikiran. Selain persoalan intransitivitas sains, Bhaskar menawarkan alternatif untuk mengatasi persoalan yang ada pada relativisme posmodernisme. Realisme transendental bukan sebagai jenis atas absolutisme epistemologi atau idealisme sekaligus mengkritik teori bebas nilai (Bhaskar, 2008). Bagi Bhaskar, ilmu tidak dapat terlepas dari relativitas.

\section{c. Epistemic Fallacy Roy Bhaskar}

Bhaskar menyatakan terdapat tiga varian realis yang paling signifikan, pertama, realisme predikatif berkomitmen terhadap yang universal dan hadir sebagai properti yang melekat terhadap suatu objek partikular; kedua, realisme perseptual meletakkan basis komitmen pada objek material yang tertutup di bawah ruang dan waktu; dan ketiga, realisme ilmiah berkomitmen pada eksistensi entitas teoritis yang secara absolut dan mandiri dari pikiran manusia.

Bhaskar dalam perdebatan ini memosisikan diri sebagai seorang realis ilmiah. Konsekuensi logisnya Bhaskar mereduksi realisme predikatif dan realisme perseptual ke dalam realisme ilmiah. Dengan begitu yang universal dan objek material terinstansiasi dalam pengetahuan ilmiah dan bersifat mandiri dari sikap dan aktivitas ilmuwan. Dari klaim tersebut menimbulkan pertanyaan, "apakah ilmu alam itu realis, atau berangkat lebih jauh?" "Apakah setiap term teoritis memiliki rujukan yang independen di luar teori?"

Posisi tersebut mengarah pada problem realisme metafisis, yaitu "dunia semacam apa yang memungkinkan adanya praktik ilmiah?" Kita menyadari bahwa tesis realisme metafisis ini bergantung pada filsafat ilmu. Berdasarkan posisi tersebut kita memahami bahwa dalam posisi Bhaskar menekankan pada "yang ada" (being) dalam praktik ilmiah. Tendensi realis ini menekankan pada resistensi "yang ada" secara mandiri dari pikiran dan tindakan manusia, yaitu dalam kerangka rasio dan pencerapan inderawi. Sehingga "yang ada" sama sekali berbeda dari apa yang diatribusikan manusia. Dengan demikian, kritik inilah yang dikenal sebagai epistemic fallacy.

Kekeliruan epistemik muncul ketika adanya reduksi kerangka metafisik dalam kerangka epistemologis sehingga kita tidak dapat melakukan primasi terhadap penyataan mengenai "yang ada" ke dalam pernyataan "bagaimana mengetahui" ada. Padangan tersebut bagi Bhaskar hanya memperlihatkan hubungan "yang ada" tanpa berusaha masuk ke dalam maksud dari adanya hubungan-hubungan tersebut sebagaimana doktrin pos-Humean.

\section{d. Kritik Realisme Empiris dan Positivisme Logis}

Realisme Kritis menolak gagasan bahwa seluruh pengetahuan manusia dapat direduksi ke dalam pencerapan indrawi. Bhaskar mengklaim bahwa kita tidak dapat mereduksi struktur mekanistik ke dalam regularitas. Bahwa "terdapat distingsi ontologis antara yang pola peristiwa (pattern of event) dan hukum ilmiah" (Bhaskar, 2014). Walau demikian, kita memahami bahwa betapa pentingnya pencerapan indrawi sebagai sumber dari pengetahuan kita terhadap dunia. Bhaskar mengakui bahwa aspek empiris juga merupakan basis yang esensial dalam pengetahuan kita terhadap dunia, tetapi ia tidak ingin membiarkan hal itu jatuh ke dalam realisme empiris. Bagi Bhaskar, menerima realisme empiris adalah membiarkan jatuh pada epistemic fallacy. Maka dalam bagian berikut ini akan dijelaskan mengenai hukum kausal dan pola-pola kejadian (patterns of events).

Realisme empiris secara umum telah ditolak oleh realisme transendental. Pembedaan antara hukum kausal dengan pola kejadian ini perlu untuk menjelaskan pentingnya ontologi dalam penjelasan sains. Pembedaan ini juga ingin mengatakan bahwa tidak cukup menjelaskan hukum kausal hanya dengan melihat hubungan-hubungan konstan (constant conjunction). 
Hal itu dapat kita lihat melalui hubungan konstan atau sebuah regularitas yang bergantung pada praksis. Praksis di sini merupakan tindakan dan aktivitas para ilmuwan di dalam laboratorium. Sesuatu yang para ilmuwan temukan di laboratorium bukanlah hukum kausal melainkan dasar empiris bagi hukum tertentu karena regularitas berdasarkan pada peristiwa empiris. Hal tersebut dianggap kurang memadai karena bila pengambilan kesimpulan didasarkan pada keadaan sistem yang terbuka (open systems), maka kurang adanya pendasaran empiris dan transendental, juga kondisi tempat hukum tersebut terjadi tidak menjamin terpenuhi di dalam kondisi-kondisi tertentu.

Kesimpulan yang dihasilkan tidak akan berlaku secara universal dan memiliki peran praktis. Hubungan-hubungan konstan atau suatu regularitas tidak dapat diterapkan dalam sistem yang terbuka, karena basisnya hanya pada kejadian (event). Dengan mendasarkan hubungan kausal pada "kecenderungan" (tendency) mekanisme daripada sekadar memberikan jaminan pada kejadian, pengetahuan mengenai hukum kausal lebih berguna dalam praktis.

Konstruksi teoritis realisme kritis secara eksplisit dijelaskan oleh Bhaskar:

Explanation thus involves, centrally, the substitution in our imagination of a real or empirical relationships for an unreal or theoretical one (Bhaskar, 2008: 145).

Dari kutipan di atas, kita dapat menerjemahkan bahwa Bhaskar tidak secara konstruktif mereproduksi relasi sebagai realitas empiris konkret yang berada di pikiran, tetapi sebagai imajinasi terhadap yang-riil. Dengan kata lain, Bhaskar menciptakan realitas alternatif teoritis nonriil yang harus secara niscaya bersifat kontradiktif. Seluruh relasi yang riil diganti dengan konsep "kecenderungan" dibandingkan dengan konsep riil seperti verifikasi. Lebih jauh Lawson menjelaskan:

\section{A statement of a tendency, in other words, is not a conditional statement about something actual or empirical but an unconditional statement about something non-actual and non-empirical (Lawson, 1997).}

Dari kalimat di atas kita dapat memahami bahwa penggunaan terminologi 'tendensi/kecenderungan' bertujuan untuk menjelaskan suatu kalimat non-kondisional mengenai suatu hal yang tidak aktual dan tidak empiris yang berlaku pada hukum seperti gravitasi. Gravitasi memiliki kecenderungan untuk membuat apel jatuh. Kecenderungan gravitasi untuk membuat apel jatuh tersebut bukanlah bersifat aktual dan empiris.

Pembedaan antara pola kejadian (pattern of event) dengan hukum kausal menegaskan sebuah keterpisahan keduanya secara ontologis. Seperti yang sudah dijelaskan di atas, hukum kausal dianalisis sebagai suatu "kecenderungan" mekanisme.

"Structures and mechanisms then are real and distinct from the patterns of events that they generate; just as events are real and distinct form the experiences in which they are apprehended." (Bhaskar, 2008: 46).

Dalam penjelasan di atas kita memahami bahwa mekanisme itu ada dan berlaku mandiri, terlepas dari pengenalan, pengetahuan, dan penggunaannya oleh sains. Problem mengenai hubungan kausal memecah filsafat ilmu ke dalam tiga tradisi, yaitu empirisme, idealisme transendental, dan realisme transendental. Empirisme, yang secara garis besar digagas oleh Hume, memiliki dua garis asumsi: pertama, epistemologi reduksionis (reductionist epistemology), yang mengklaim bahwa semua pengetahuan harus dapat diderivasikan dan dijustifikasikan oleh pengalaman indrawi, yang kemudian dipertanyakan oleh Kant dan ontologi empiris. Setidaknya terdapat tiga poin penting dalam kritik Kant terhadap Hume. Pertama, kekurangan kriteria tambahan bagi penetapan hukum. Kedua, ketidakmampuan suatu teori bertahan berdasarkan suatu teori yang bertentangan. Ketiga, ketidakmampuan untuk memberikan basis rasional bagi perkembangan ilmiah.

Kritik realisme transendental terhadap kritik Kant memiliki penekanan yang sama. Pertama, idealisme transendental memiliki kekurangan dan ketidakmampuan untuk menjadi basis bagi syarat-syarat alami. Idealis transendental hanya berbicara mengenai klaim yang tidak terbantahkan dari suatu hukum, tetapi tidak berbicara mengenai keteraturan, kecenderungan, dan daya yang tak terelakkan dari suatu mekanisme yang bekerja di alam semesta. Selain itu, suatu hal yang luput dalam idealisme transendental adalah tidak membicarakan adanya 
mekanisme generatif. Mekanisme generatif memiliki peran sebagai dimensi intransitif dalam diskursus sains. Jika mekanisme generatif tidak ada, maka tak ada akses terhadap dunia, atau dengan kata lain sains tidak bisa membicarakan apapun. Sains itu sendiri sudah sewajarnya memiliki dasar dan mampu untuk diteliti. Bhaskar menegaskan bahwa 'tak ada dimensi transitif tanpa dimensi intransitif'. Kritik ini tertuju terhadap Kant mengenai pengetahuan yang dibangun dalam kerangka penerapan Kant dalam sains praktis. Idealisme tidak memiliki karakter dinamis yang tidak mencukupi, yaitu dalam penjelasan Kant hanya mengklaim bahwa mekanisme alam itu ada, tetapi tidak menyatakan kemandirian suatu mekanisme terhadap aspek sosial dan kerja ilmuwan.

Tradisi yang dominan dalam sains yaitu menerima hukum kausal sebagai suatu hal yang aktual. Berdasarkan kategori pengalaman, ada tiga wilayah realitas, yaitu domain empiris (De), domain aktual (Da), dan domain riil (Dr). Berdasarkan penjelasan bentuk tradisi ilmiah ini antara lain: empirisme, idealisme transendental, dan realisme transendental terhadap mekanisme generatif, maka dapat dijabarkan penjelasan ketiganya sebagaimana berikut. Empirisme memiliki formula $\mathrm{Dr}=\mathrm{Da}=\mathrm{De}$. Skema itu menjelaskan pereduksian domain yang riil kepada domain pengalaman empiris. Idealisme transendental memiliki formula $\mathrm{Dr}>\mathrm{Da}>\mathrm{De}$. Pada model ini menggambarkan adanya kerenggangan konseptual dan saling terlepas terhadap objek-objek dalam domain realitas tersebut. Sedangkan realisme transendental digambarkan sebagai $\mathrm{Dr} \geq$ $\mathrm{Da} \geq \mathrm{De}$, dalam skema tersebut pengetahuan terhadap "yang riil" dapat dimungkinkan dengan mempelajari yang empiris. Dengan demikian kita dapat menarik kesimpulan bahwa empirisme klasik memandang "hubungan konstan kejadian-kejadian" (constant conjunction of events) adalah niscaya dan memadai bagi hukum, idealisme transendental hanya menerimanya sebagai yang niscaya tetapi tidak memadai, sedangkan realisme transendental menganggapnya tidak niscaya dan tidak memadai bagi hukum.

\section{e. Kritik Relativisme Posmodernisme}

Posmodernisme dapat dipahami sebagai penolakan terhadap gagasan positivistik yang menekankan bahwa teori netral dari observasi. Tesis utama dari posmodernisme adalah bahwa relasi sosial dalam suatu komunitas ilmiah mendeterminasikan aspek ontologis, epistemologis, aksiologis, metodologis, dan etiologis yang diasumsikan oleh para ilmuwan dan peneliti (Sousa, 2010). Kecenderungan relativisme ini yang yang mengorelasikan seluruh basis ontologis, epistemologis, metodologis, aksiologis, dan etiologis per se terhadap kerja sosial, klaim tersebut yang ditolak oleh Bhaskar. Karena bagi Bhaskar, klaim tersebut mereduksi seluruh kebenaran sains ke dalam konstruksi sosial, sehingga yang ditawarkan oleh Bhaskar adalah tetap melihat sains secara epistemologis sebagai produk sosio-historis, tetapi entitas dan mekanisme yang bekerja dalam alam semesta mandiri dari sains.

Pada pandangan posmodernisme menganai pengetahuan terhadap dunia, tidak ada kebenaran yang absolut atau sifat objektif terhadap kenyataan. Hal yang dapat dilakukan manusia hanyalah interpretasi alam semesta yang seluruhnya didasarkan pada konstruksi sosial. Secara basis epistemologis, posmodernisme mengandaikan pengetahuan kita terhadap dunia dibangun di bawah suatu interaksi sosial dan tertutup di bawah konvensi, bahwa setiap pengetahuan memiliki karakter tidak dapat diperbandingkan. Bagi realisme kritis pengetahuan kita terhadap dunia bersifat berlipat (multiple), pengetahuan secara parsial terkonstruksi sosial dan menekankan pada deskripsi, eksplanasi, dan prediksi terhadap "kecenderungan”.

\section{f. Epistemologi Relativitas sebagai solusi atas Kekeliruan Epistemik}

Penjelasan sebelumnya telah menggambarkan beberapa kelemahan positivisme, antara lain berkomitmen pada mind-dependent world, menyederhanakan eksplanasi dan prediksi, deduksi-induksi menjadi dasar regulatias peristiwa konstan, adanya sistem yang tertutup padahal berpijak pada penyederhanaan atau pereduksian realitas, konsep kausalitasnya berdasar pada relasi sebab-akibat, dan termasuk teori observasi yang diandaikan netral (Sousa, 2010).

Pada sisi lain, Bhaskar menolak bagaimana gagasan posmodernisme yang meletakkan dasar ontologinya pada sosial-konstruktivis, yang dinilai sangat mengarah pada kekeliruan epistemik dalam memandang sains atau yang dikenal dengan istilah relativisme epistemologis. Ilmu kemudian secara definisi menjadi sangatlah sempit entah direduksi hanya sekedar pada tautan kuasa politis manusia atau bahkan ilmu yang tanpa pijakan dan terkesan bebas (anarkis). Artinya, ilmu tidak boleh hanya berbasis pada diskursus yang menempatkan sebab fundamental pada kesadaran manusia akan dunia (Sousa, 2010). 
Adanya kritik atas dominasi pandangan epistemologis positivisme maupun posmodernisme dalam ilmu menjadikan perlunya membangun gagasan epistemologi yang mandiri untuk mengatasi kedua persoalan tersebut. Bhaskar mengkritik secara tegas apabila adanya reduksi ontologis yang berdasar pada cara idealisme bekerja yang hanya berdasar pada pengetahuan fiksi, semacam permainan kata dari pendirian adanya realitas itu sendiri. Sebagaimana pseudosains yang menarik keumuman fiksi, filsafat juga demikian, sudah seharusnya dipandang secara partikular daripada universal. Oleh karenanya, filsafat selalu berhubungan dengan konteks, termasuk ilmu itu sendiri, pasti akan mengarah pada sejarah dan sosial. Namun, kontekstualisasi ini bukan menjadikan ilmu kemudian semacam relativisme atau tanpa reliabilitas objek yang mandiri, justru dengan adanya tawaran realisme menjadikan suatu kondisi yang mungkin terhadap aktivitas pengalaman ilmuwan melalui dunia yang terbuka dan terstruktur. Filsafat tidak mungkin mengantisipasi struktur dunia seperti sesuatu secara sempurna, akan tetapi menyisakan persoalan untuk diteliti, pun demikian, filsafat realisme kritis tidak akan pernah bebas sanggahan, Bhaskar menyebutnya filsafat harus selalu open-ended (Bhaskar, 2009).

Realisme yang open-ended ini menyisakan ruang yang perlu dieksplorasi yakni sejauh mana kesadaran atau proses refleksi diri dan pikiran terhadap dunia. Keduanya berkaitan pada aspek intrinsik (normatif) dan aspek ekstrinsik (penyebab/historis). Kesadaran pertama cenderung menilai dan memperhatikan masalah validitas, sedangkan poin kedua dikenal dengan sifatnya yang historis dan mempertanyakan perihal kredibilitas. Kedua aspek ini menjadikan epistemologi ilmu itu mungkin. Tidak hanya sekadar cara mengetahui sesuatu, tetapi juga sekaligus pemahaman akan kesadaran itu sendiri.

Bhaskar menyadari bahwa sains yang memadai/kompeten selalu berhubungan dengan argumentasi ontologi, epistemologi, bahkan sosiologi tertentu. Akan tetapi, sepanjang sejarah ilmu, sadar atau tidak sadar, ilmuwan telah bekerja pada ranah pereduksian beberapa level struktur realitas, misalnya kajian filosofis direduksi menjadi kajian psikologis. Tidak hanya pada ranah ilmu, lingkup filsafat pun sering terjadi pereduksian dari "yang ada" menjadi "yang diketahui", ontologi ke epistemologi atau sering disebut kesalahan epistemik, sedangkan kebalikannya disebut kesalahan ontis. Termasuk bagaimana ilusi spekulatif bekerja pada ranah filsafat sebagaimana ilusi positivistik ilmu secara umum mendominasi (Bhaskar, 2008).

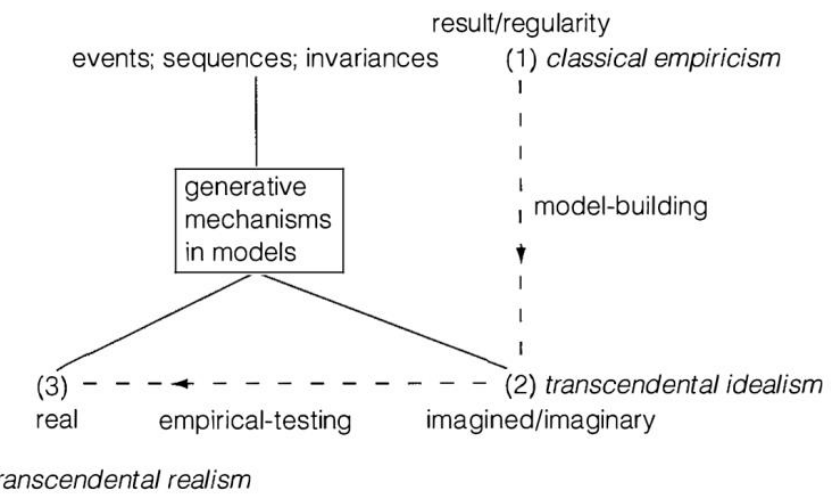

Gambar 2. Logika Temuan Ilmiah (Bhaskar, 2008: 135).

Penjelasan epistemologi Bhaskar dapat dipahami melalui logika temuan ilmiah yang disusun untuk menjelaskan bahwa realisme kritis atau realisme transendental bekerja berdasarkan stratifikasi realitas. Hal ini mengandaikan pandangan epistemik seorang ilmuwan bergerak mulai dari memahami hasil regularitas, membangun model, melakukan pengujian untuk mencari titik temu terhadap mekanisme/daya kausal, lalu kemudian dimodelkan. Bhaskar kemudian mencari solusi pada ranah ontologis dengan menawarkan realisme kritis sedangkan sayap epistemologis disebutnya sebagai relativitas epistemologis.

Relativitas berbeda dengan relativisme. Hal ini dapat merujuk pada gagasan dimensi transitif sains, bahwa semua kepercayaan dan pengetahuan manusia merupakan produk sosiohistoris, oleh karenanya, sangat mungkin dapat keliru. Rasionalitas putusan kemudian menjadi metode lanjutan untuk menyangkal relativisme putusan. Kritiknya ialah bahwa semua kepercayaan/pengetahuan sama benarnya sebab tak ada kriteria dasar-universal yang dapat 
memilah pengetahuan yang benar dari yang keliru (Archer et al., 2013). Artinya, tidak ada kepastian apapun jika semuanya kemudian direlatifkan secara radikal yang akan mengarah pada skeptisisme terhadap objek ilmu yang independen.

\section{Simpulan dan Saran}

Epistemologi menjadi salah satu lokus pembahasan Roy Bhaskar secara implisit dalam beberapa karyanya. Hal ini didasarkan dari pandangan filosofisnya yang dikenal sebagai Realisme Kritis. Melalui Realisme Kritis dapat ditarik satu simpulan sederhana bahwa epistemologi menjadi bagian penting dari pembahasan filsafat ilmu. Epistemologi menurut Bhaskar dalam konteks realisme kritis harus bersifat relativis daripada merujuk pada relativisme. Relatif berarti seluruh pengetahuan tentang sains dapat saja keliru karena bertautan dengan dimensi transitif dan ranah sosial ilmuwan ketika mereka bekerja. Artinya, sains bukan sekadar produk sosial-historis, tetapi menjadi entitas dan mekanisme yang bekerja secara mandiri dari sains, atau dengan kata lain, secara epistemologis selalu bersifat terbuka untuk dapat keliru. Untuk memastikan tidak terjatuh pada relativisme absolut ataupun skeptisisme radikal, pengetahuan dalam realisme kritis dinyatakan sebagai hasil produk konstruksi sosial secara parsial melalui manipulasi atau intervensi terhadap dunia, dan melakukan penekanan pada deskripsi dan eksplanasi melalui prediksi tendensial atau 'kecenderungan'.

Adapun hasil secara praksis yang didapat dari penelitian ini ialah mengarah pada bagaimana seharusnya sikap ilmiah dari seorang ilmuwan. Ilmuwan boleh saja memilih menjadi seorang positivisme yang tulen atau bekerja di bawah pijar semangat emansipatoris ala posmodernisme, namun ada hal yang tidak boleh dilupakan oleh ilmuwan bahwa perlu adanya cara pandang yang berbeda tentang bagaimana dunia yang memungkinkan adanya sains. Realisme kritis menjawab persoalan tersebut melalui gagasannya yang dinamakan realisme transendental, epistemologi relativis, dan putusan rasionalitas. Implikasi praksisnya dapat bekerja pada komitmen ontologis seorang ilmuwan dalam melihat realitas dan sains secara terbuka (realisme transendental), berpegang teguh pada keterbukaan epistemik (epistemologi relativis), dan menentukan nilai secara rasional (putusan rasionalitas).

\section{Ucapan Terimakasih}

Artikel jurnal ini sebagai bagian dari publikasi penelitian berjudul 'Pandangan Epistemologi dalam Realisme Kritis Roy Bhaskar' dan laporan hibah penelitian pengembangan mata kuliah BPPTN-BH Fakulas Filsafat, Universitas Gadjah Mada 2020.

\section{Daftar Pustaka}

Archer, M., Bhaskar, R., Collier, A., Lawson, T., \& Norrie, A. (2013). Critical Realism: Essential Readings. UK: Routledge.

Bhaskar, R. (2008). A Realist Theory of SCience. UK: Routledge.

Bhaskar, R. (2009). Scientific Realism and Human Emancipation. UK: Routledge.

Bhaskar, R. (2014). The Possibility of Naturalism: A Philosophical Critique of the Contemporary Human Sciences. UK: Routledge.

Bird, A. (2010). The Epistemology of Science-a Bird's-eye Vlew. Synthese, 175(1), 5-16.

Chakravartty, A. (2007). A Metaphysics for Scientific Realism: Knowing the Unobservable. UK: Cambridge University Press.

Chakravartty, A. (2011). Scientific Realism. Plato Stanford Encyclopedia of Philosophy.

Fleetwood, S. (2014). Bhaskar and Critical Realism. Oxford Handbook of Sociology: Social Theory and Organization Studies, Oxford University Press, Oxford, 182-219.

Hacking, I. (1984). Experimentation and scientific realism. In Science and the Quest for Reality (pp. 162-181). Berlin, Heidelberg: Springer.

Hartwig, M. (2015). Dictionary of Critical Realism. UK: Routledge.

Kitcher, P. (1984). The Nature of Mathematical Knowledge. UK: Oxford University Press.

Lawson, T. (1997). Economics and reality (Vol. 9). UK: Psychology Press.

Niiniluoto, I. (1999). Critical Scientific Realism. UK: Oxford University Press.

Pritchard, D. (2018). What is this Thing Called Knowledge? UK: Routledge.

Schaffer, J. (2009). On What Grounds What. Metametaphysics, eds. David Chalmers, David Manley, and Ryan Wasserman: 347-83. UK: Oxford University Press.

Sousa, F. J. (2010). Metatheories in research: positivism, postmodernism, and critical realism. In 
Organizational culture, business-to-business relationships, and interfirm networks. UK: Emerald Group Publishing Limited.

Suryajaya, M. (2014). Warisan Pemikiran Roy Bhaskar. Retrieved from https://indoprogress.com/2014/12/warisan-pemikiran-roy-bhaskar/

Suryajaya, M., \& Apinino, R. (2016). Mencari Marxisme. Jakarta: Marjin Kiri.

Van Fraassen, B. C. (1980). The Scientific Image. UK: Oxford University Press.

Wenning, C. J. (2009). Scientific Epistemology: How scientists Know What They Know. Journal of Physics Teacher Education Online, 5(2), 3-16. 